\title{
On Being Fully Professional
}

By ARTHUR T. HAMLIN

ALA Membership DAY-March 18is an opportunity for all libraries and librarians to become fully professional by joining their professional organization. At present less than fifty per cent of those who rank as professional librarians in colleges and universities are members.

This lack of membership seriously weakens the prestige and authority of ALA, and the lack of financial support curtails its program.

Since membership is a voluntary matter that requires personal sacrifice in the form of annual dues many librarians quite naturally ask themselves what the association does for them. In blunt terms the query is, "What do I get for my money?" The only true answer to this question that I have ever found that is applicable to all librarians is that we all benefit individually and directly as the Association serves the profession. Not only our individual benefits, but our strength, comes in union.

Every single advance and accomplishment of the profession is of benefit to each of its members. On the one hand this may be a new code for interlibrary loans or standards for college libraries. Or the advance may come as national legislation or a program of grants for college libraries. Much has been done over the years toward the improvement of salaries and professional status. Few if any librarians ever do a day's work of a professional nature without using ALA-developed publications, procedures, and techniques. Our very training is taken at schools over which our national association exercises important control.

Nearly all members have at some time felt lost and unrecognized because offices and committee assignments have not come their way. For some this situation
Mr. Hamlin is University Librarian, University of Cincinnati.

changes so drastically with age and experience that much of the working day and considerable personal funds are spent in ALA activity; to these people less recognition would be a great relief. Inequalities of burden and recognition are inevitable in any large organization. Equally inevitable is the fact that no association action wins universal approval. There are undoubtedly few members of any great, active, democratic organization who could not, if they wished, make up a plausible case for withdrawal of their support.

ALA has proudly maintained its membership on a purely voluntary basis. There has never been coercion on either the national or the local level, and ours is one of the very few professions which can claim this distinction. Other professions openly require membership for the privilege of practicing, or they exert subtle pressure in less obvious ways. It seems hardly necessary to point out that freedom in political organization and in professional affairs must have moral and financial support. The alternative is coercion.

This is the time for each and every librarian to stand up and be counted. Individually and collectively we need a strong professional association. In order to grow stronger the Association needs additional membership, not only for the dues involved, but to speak with greater authority to Iegislatures, to other professions, and to the country at large. Only in union is there strength.

COLLEGE AND RESEARCH LIBRARIES 